\title{
Profesora Marka Jana Siemka imperium fliboofi prawa
}

\section{Ewa Nowak}

\section{Professor Mareh Jan Siement's empirie of phillosophy of law}

Abstract: In his philosophical opus Marek J. Siemek not only revisited Hegelian two-stage developmental model of the law. He also created his own legal philosophy which is rooted in the tragic conflict of Greek Sittlichkeit. Siemek, however, clearly demonstrates how can an abstract legal system achieve its ethical (sittliche) qualities at modern times, as being mediated by the structures of reciprocal recognition. Siemek's unique proposal belongs to the neo-positivist and, at the same time, to the post-positivist approaches of the law. The author focuses on the intellectual potential of Siemek's legal and social thinking as well as on his concept of philosophizing in the era of permanent crisis we experience again today

Keywords:legal philosophy, ethical evolution of the abstract law, mutual recognition, Sittlichkeit, Siemek, Hegel

\section{Wprowadrenie}

W dorobku filozoficznym Marka J. Siemka topos prawny zajmuje miejsce centralne, poczynając od jego rozprawy habilitacyjnej pt. Idea transcendentalizmu u Fichtego i Kanta. Dzieli on to miejsce z toposem moralnym o tyle, o ile nowoczesność - jak zapowiada Hegel - wytwarza prawna (Recht) raczej aniżeli moralną (Tugend) zasadę etyczności (Sittlichkeit). Przyjmujac za Heglem prymat prawa nad moralnościa, Siemek podejmuje ogromne wyzwanie. Wszak „wolność

\footnotetext{
* Uniwersytet im. Adama Mickiewicza w Poznaniu ewanowak@bluewin.ch
} 
jako zasada świata nowoczesnego" trawi wewnętrzny rozłam, napięcie i - jak powiada Siemek - kryzys. Polega on na tym, że praźródłem prawa moralnego i pozytywnego jest wprawdzie jedna i ta sama wola i wolność ludzka, ale rozszczepiona na indywidualny i indywidualizujący, z jednej strony, społeczny zaś i uspołeczniający, z drugiej, żywioł. Siemek należy do tych, którzy temu właśnie wyzwaniu, wyartykułowanemu już w greckiej tragedii, zawdzięczają moc swojej filozofii i właściwy jej patos. Skoro bowiem „napięcie między jednostką a jej nowopowstająca przestrzenią społeczno-duchową stało się nie do wytrzymania", skoro ani sztuka, ani religijne sacrum nie sa w stanie rozwiązać tego „kryzysu tożsamości" nowoczesnej, i kto wie, czy rozwiazać potrafi go zawłaszczająca, ale i spłaszczająca sens ludzko-społecznej egzystencji, moc nauki, pozostaje nam zwrócić się ku filozofii. Albowiem

zupełnie inaczej jest z filozofia... Filozofia jest tu u siebie w domu, jako „endemiczna” postać życia duchowego w kryzysowo rozszczepionej immanencji świata „tetycznego"... Filozofia powstaje dopiero wraz z tym światem i jako wyraz drążących go wewnętrznych sprzeczności ${ }^{2}$.

W taki właśnie sposób pojmował Siemek credo własnej działalności filozoficznej. Jest ono dziś bardziej aktualne niż kiedykolwiek, wszak tożsamość filozoficzna sama znalazła się w głębokim kryzysie.

Kryzys zawsze potęguje u człowieka nieodparta i niezbywalna potrzebę oparcia w jakimś sensownym ładzie. Jednakże w epoce nowoczesnej ład nie jest dany odgórnie. Ludzkość musi go stwarzać - a zasadniczo, wynajdować na nowo - samodzielnie, immanentnie, inaczej niż to się dzieje w porządku transcendentnym albo przyrodniczym. Porządek tworzony przez człowieka wespół z innymi, czyli porządek społeczny, jest porządkiem z gruntu odmiennym od tamtych. Powstawanie relacji oraz instytucji społecznych, politycznych i prawnych opiera się tutaj na działaniu tetycznym i nomotetycznym. Nie od razu stają się one

1 Marek J. Siemek, Hegel i filozofia, Terminus, Warszawa 1998, s. $67-88$.

1 M. J. Siemek, Wolność, rozum, intersubiektywność, Terminus, Warszawa 2002, s. 30-31. 


\section{Ema lowak |}

pochodnymi działania wolnego i rozumnego; znamion tych nabieraja w miarę żmudnego i powolnego rozwoju ludzkiej wiedzy i samowiedzy, a także kompetencji społecznych, do których należy m.in. intersubiektywny stosunek uznania, umożliwiający zastapienie brutalnych w swej bezpośredniości mechanizmów regulacyjnych, do jakich należą m.in. konflikt społeczny i abstrakcyjny przymus prawny, bardziej rozumnymi i społecznie zapośredniczonymi mechanizmami i instytucjami. Jako bardziej zhumanizowane i uniwersalne, będą one z czasem zasługiwać na miano etycznych (sittlich).

Chcemy tutaj zrekonstruować pojęcie prawa jako fundamentalnej instytucji społecznej wedle Marka J. Siemka, rozważając najpierw narodziny prawa „abstrakcyjnego" w jego odrębności i samoistności w stosunku do prawa moralnego, a następnie wykazując rozwój tego pierwszego, polegający na tym, że prawo abstrakcyjne przybiera coraz więcej znamion bądź jakości etycznych, i jako takie dopiero zyskuje prymat wobec moralności. W centrum naszych rozważań, dedykowanych pamięci Profesora Marka J. Siemka, stać będzie zatem pojęcie prawa w jego nieredukowalnej i zasadnej skądinąd dwoistości, ale także w jego zastosowaniu jako kryterium etyczności każdego istniejacego systemu prawnego. Na koniec zaś spróbujemy rozstrzygnąć, do kogo należeć powinien decydujący głos w filozofii prawa XXI w. - czy głos ten będzie tylko pogłosem pozytywizmu prawniczego, który zdominował namysł nad istotą prawa w wieku XX i zarazem ograniczył ów namysł do „filozofii prawników" (jak wyraził to w swej najnowszej książce Jerzy Zajadło), czy też wybrzmi w nim na nowo i w pełni wezwanie pod adresem tych, którzy odpowiadaja za legislację lub za orzecznictwo, aby nadawali prawu bądź odsłaniali w nim jego etyczne jakości, umożliwiając człowiekowi osiąganie prawnej samowiedzy, jako należnej autonomicznemu i etycznemu, i w tym sensie dopiero nowoczesnemu społeczeństwu. Retrospektywa dokonań Siemka w zakresie rozwoju pojęcia prawa pozwala odpowiedzieć na pytanie, dlaczego używał pojęcia „późna” bądź „spełniona” nowoczesność zamiast, przykładowo, pojęcia „ponowoczesność”. Otóż powszechnie wiadomo, że projekt nowoczesności pozostaje niedokończony w sferze etycznego rozwoju prawa, podczas gdy w innych sferach wydawać się może zamknięty 
lub wyczerpany. Filozofia prawa - taka, jaką uprawiał Siemek - poczuwa się do zbyt wysokiej odpowiedzialności społecznej, aby projektu tego zaniechać. Siemkowi udało się zdefiniować warunki, w jakich rozwój prawa osiaga stadium etyczne. Co więcej, udało mu się zidentyfikować te warunki w samym centrum prawa, podczas gdy refleksja nad prawem, wywodząca się z fillozofii jako macierzystej i często jedynej dziedziny, ogranicza się do dyskursu społecznego jako źródła legitymizacji abstrakcyjnych norm prawnych, zwanych inaczej generalnymi. Siemek zaś penetruje pojęcie prawa nie mniej głęboko, aniżeli czynią to badacze wywodzący się z nauk prawnych.

\section{Nomothesis. ,Irnagedia w Ionie etycanosicl”}

Wedle helleńskich przekazów moralność i prawo pojawiaja się na scenie życia społecznego od razu jako nawzajem przeciwstawne, „zwaśnione” i „obrażone” moce etyczne, z niezrównaną siłą wyrazu odmalowane przez Sofoklesa w postaciach Antygony i Kreona. Tragiczny rozłam w naturalnej i substancjalnej, bezpośredniej i samooczywistej „totalności” ${ }_{3}$ etycznej wydał z siebie rozliczne „binarne” opozycje miłości i racji, moralności i prawa, rodziny i państwa, transcendencji i immanencji, sacrum i profanum. Nade wszystko jednak zrodził on „,stan rozdarcia i trwały kryzys tożsamości w całym ludzkim życiu, myśleniu i działaniu. Człowiek znajduje się tu nie jednorazowo i przejściowo, lecz właśnie stale w polu nieusuwalnego napięcia..." zwłaszcza pomiędzy gestem ziemskiego, jawnego prawodawcy a odwiecznymi, w ludzkim sercu i sumieniu wyrytymi prawami moralnymi, za którymi skrycie podążyła Antygona.

Strażnik do Kreona -

A więc już powiem. Trupa ktoś co tylko

Pogrzebał skrycie i wyniósł się chyłkiem;

Rzucił garść ziemi i uczcił to ciało ${ }^{5}$.

3 M. J. Siemek, Filozofia spetnionej nowoczesności-Hegel, Wydawnictwo UMK, Toruń 1995, s. 67.

4 M. J. Siemek, Wolność, rozum, intersubiektywność, dz. cyt., s. 29.

5 Sofokles, Antygona, przeł. K. Morawski, Tower Press, Gdańsk 2000, Prolog. 
Kreon -

Wydałem rozkaz, by chować ni płakać

Nikt się nie ważył, lecz zostawić ciało

Przez psy i ptaki w polu poszarpane... ${ }^{6}$

Ismena -

Niczym dla ciebie więc zakaz Kreona?

Antygona -

Niczym, on nie ma nad moimi prawa... ${ }^{7}$

Wiedziałam dobrze. Wszakże [rozkaz] nie był tajny.

Nie Zeus to przecież obwieścił to prawo

Ni wola Diki, podziemnych bóstw siostry,

Taką ród ludzki związała ustawa.

A nie mniemałam, by ukaz twój ostry

Tyle miał wagi i siły w człowieku,

Aby mógł łamać święte prawa boże,

Które sa wieczne i trwają od wieku,

Że ich początku nikt zbadać nie może.

Ja więc nie chciałam ulęknąć się człeka

I za złamanie praw tych kiedyś bogom

Zdawać tam sprawę 8 .

Najwyraźniej akt nomothesis stanowi odpowiedź na bezprawność określonego działania w porządku politycznym, ale i profanicznym, radykalnie odmiennym od eschatologicznego, z którego czerpała niegdyśs ludzka moralność. Następstwa tego aktu stawiają filozofujaccy umysł przed szeregiem wyzwań poznawczych i praktycznych. Weźmy zachwiana i domagająca się przywrócenia równoprawność wewnętrznej, odwiecznej, z boskiego nadania pochodzącej „zasady serca" w stosunku do zewnętrznej, ludzkiej li tylko i świeckiej „zasady rozumu”. Najwyraźniej bowiem druga z tych zasad, czyli „publicznie ogłaszane i jawnie egzekwowane ustawodawstwo" obróciła się przeciwko pierwszej, starając się ją podważyć i unieważnić. Wszelako, gdyby rozkaz Kreona nie posiadał żadnej legitymizacji i czerpał cała moc swego obowiązywania stąd, że „ius positum, zwane inaczej ius positivum, stanowione jest przez władcę i zaprowadzane za pomoca

\footnotetext{
6 Tamże, Parodos.

1 Tamże, Parodos.

8 Tamże, Epeisodion 2.

$?$ M. J. Siemek, Hegel i filozofia, dz. cyt., s. 93.
} 
środków przymusu" ${ }^{10}$, to wówczas byłoby ono istotnie pozbawione mocy - i to nie tylko nadrzędnej, ale i równorzędnej wobec etycznej mocy prawa moralnego. Polinejkes dopuścił się jednak zdrady, a Kreonowy zakaz pochówku stanowił formę kary dla sprawcy. Podstawą wydania zakazu było wobec tego bezprawie ${ }^{11}$, skutkiem zaś - postawienie Antygony w obliczu dylematu między dwoma równie słusznymi prawami. Dylemat ma to do siebie, że wybór którejkolwiek zasady pociaga za sobą nieuchronnie „obrazę” tej drugiej, niewybranej zasady. Skoro źródłem dylematu jest równoprawność, to nie należy upatrywać w niej jego rozwiązania. Skoro nomotetyczny akt Kreona miał legitymację nie tylko w samej „nakazowości” normy i woli dawcy tejże normy, można w nim widzieć zalążek prymatu prawa nad moralnością. Na przesileniu pomiędzy prawem i moralnością umocował Hegel swoje przekonanie, że nowoczesność należeć będzie bardziej do prawa aniżeli do cnoty.

Jednakże owa fundatorska, wczesno-nowoczesna odrębność dwóch opisanych „zasad”, różnica i wreszcie konflikt między nimi mogą i powinny niepokoić zwłaszcza wtedy, gdy zestawimy je z niepojętą perwersją i ślepym posłuchem, jakie doszczętnie skompromitowały akt tetyczny i pozytywistyczną regułę „prawo znaczy prawo, rozkaz znaczy rozkaz” (G. Radbruch) w okresie 1933-45, na który przypadać miała dojrzała nowoczesność. W świetle tego ostatniego doświadczenia nomothesis wymaga bezwarunkowo legitymizacjijednakże ta ostatnia, co dobrze widać w twórczości Marka Siemka, nie może się ograniczać do dyskursywno-komunikacyjnych procedur i republikańsko-demokratycznych kontekstów kształtowania się woli prawotwórczej.

\section{Marka I. Siemka projekt nowocressego pojecia prawa}

W swym projekcie rozwoju pojęcia prawa, polegającym na przybieraniu jakości etycznych przez prawo pozytywne, ,abstrakcyjne" i „generalne” w swoim normatywnym wydźwięku,

${ }^{10}$ M. Kriele, Grundprobleme der Rechtsphilosophie, LIT Verlag, Münster, Hamburg, London 2003, s. 3-4.

" Hans Kelsen, Reine Rechtslehre 1960, Unveränderter Nachdruck, Frank Deuticke, Wien 1983, s. 116-119. 


\section{8 | Ewa lowak |}

jaki znamy z kodyfikacji prawnych, Siemek proponuje coś nowego i znacznie bardziej „substancjalnego” w porównaniu do współczesnych propozycji proceduralistycznych.

Odsłania przy tym pewną myląca dwuznaczność Heglowskiej filozofii prawa. U Hegla bowiem krytyczno-realistyczny obraz społeczeństwa, wciąż jeszcze niegotowego, by tworzyć etyczne prawo - czyli w rzeczy samej ludu przedetycznego, „który w oderwaniu od rządu raczej nie wie czego chce... a przecież największym osiagnięciem człowieka jest wiedzieć, czego się chce" (Phil. des Rechts, 1819, s. 260) sąsiaduje z obrazem społeczeństwa złożonego z obywateli o rozwiniętej samowiedzy, zdolnego upominać się o etyczną jakość prawa, skądinąd niezbywalnie „abstrakcyjnego”.

Samowiedzy prawnej nowoczesnego indywiduum przypisać należy m.in. to, że prawo abstrakcyjne zachowuje dystans do moralności i subiektywności, toteż nie może się ono jednać, a tym bardziej łączyć z czyjąkolwiek i jakkolwiek pojęta moralnością w taki sposób, by odtwarzać mityczna „jedność”. Zasadniczo, u Hegla znajdujemy pełną wykładnię tezy o separacji prawa i moralności, którą wsławił się Hans Kelsen w XX w. Siemek zaś jest jednym z niewielu filozofów prawa, którzy potrafili przekonująco uzasadnić teze o separacji, eksplorujac Heglowskie rozumienie etyczności. Dlatego też oddaje on sprawiedliwość prawu abstrakcyjnemu, widząc w nim wprawdzie „niższe”, tym niemniej - nieusuwalne, bo w pełni już etyczne (sittlich) stadium rozwoju prawa. Później dopiero wskaże kierunek rozwoju prawa abstrakcyjnego jako etyczności niezależnej i samoistnej wobec moralności. Podkreśla on, że

Ostre i nieusuwalne rozdziały między... normatywnością moralną i prawna... moga zostać jasno wyartykułowane i odniesione do siebie nawzajem tylko poprzez pośrednią i fragmentaryczną uniwersalizację właściwa „abstrakcyjnemu prawu" w przeciwieństwie do moralności. To nie moralność więc, lecz prawo (również w swej „abstrakcyjności”, z której właśnie czerpie bezwyjątkowość swego obowiązywania) przedstawia sobą według Hegla istotę nowoczesnej etyczności. W nim bowiem ma swe reguły społeczna rozumność, tworząca się w komunikacyjnym dialogu. Jest to rozumność z gruntu nie „fundamentalna”... Jest tylko - i aż - prawomocna $i$ praworzadna racjonalnościa umowy, sprawiedliwej 
wymiany, wzajemności świadczeń i oczekiwań... która wszystkim zainteresowanym wyznacza te same, jednolite normy i miary. I dlatego jest też tylko limitacyjnq racjonalnością odgraniczeń, odstępów i porównań. Umożliwia komunikację pomiędzy różnymi podmiotami - jednostkowymi i grupowymi - tylko dzięki temu, że wytycza między nimi wyraźne linie demarkacji i swe roszczenia do powszechnej ważności... łączy ze ściśle zachowywanym dystansem wobec intymnej prywatności tego, co po prostu indywidualne. I nade wszystko w tym widać głębię Heglowskiego wejrzenia w „etyczność” prawa jako zasadę naszego nowoczesnego świata ${ }^{12}$.

Zgodnie z Siemkowską interpretacja pojęcia „niższego” prawa, wyłożonego przez Hegla w Zasadach filozofii pra$w a$, abstrakcyjność lub inaczej „generalność” norm prawnych jest nieusuwalnym znamieniem prawa. Na pierwszy rzut oka zawiera ona czysto formalne i negatywne zadatki bądź znamiona „etyczności”, których doniosłość zbyt często uchodzi naszej uwadze; a dzieje się tak, ponieważ indywiduum trudno rozpoznać się w „abstrakcyjnym” prawie zwłaszcza na poziomie sformułowań normatywnych, bez pomocy interpretacji i wykładni prawniczej. Wprawdzie Hegel w paragrafach 29-30 swej Filozofii prawa odróżnia dwa pojęcia prawa, „niższe” prawo abstrakcyjne i „wyższe” prawo etyczne, i podobnie postępuje Marek Siemek; jednakże prawo „wyższej”, etycznej rangi ${ }^{13}$ nie uprawnia do

1 M. J. Siemek, Hegel i filozofia, dz. cyt., s. 107.

B Również z punktu widzenia aksjologii prawa. Heglowska filozofia prawa proponuje aksjologię w specyficznych kontekstach, zaś Marek Siemek - rozważając ją explicite m.in. na przykładzie wartości takich, jak wolność i własność, zainspirował autorkę do próby aksjologicznej interpretacji etyczności, zob. E. Nowak, „Experimenting with values in legal contexts. Hegel and Radbruch”, Experimental Ethics. A Multidisciplinary Approach, LIT Verlag, Münster 2014, s. 115-140. Dla porównania, współczesne próby rozgraniczania aksjologii i prawa przybierają kierunek zgodny z tezą o separacji prawa i moralności. Przykładowo, „pozytywistyczna ,ucieczka’ od wartości w przypadku Raza jest tylko przeprowadzeniem koniecznych, jego zdaniem, granic między prawem a wartościami — nie jest natomiast zanegowaniem istoty oddziaływania wartości na prawo, m.in. w toku uzupełniania braków danego systemu prawa. Joseph Raz powiada, iż mocna teza społeczna jest aksjologicznie neutralna”, pisze T. Kozłowski, „Społeczny pozytywizm Josepha Raza”, Studia Iuridica, XXXVI/1998, s. 99. 


\section{BO | Ema llowak $\mid$}

deprecjonowania prawa abstrakcyjnego „niższej” rangi. Prawo w jakości etycznej jest wszak tym samym abstrakcyjnym prawem, które posiada pewne nowe, odmienne od abstrakcyjnych znamiona. I niech nie zwiedzie nas retoryka Hegla, znamienna zwłaszcza dla niektórych paragrafów Filozofii prawa, wedle których prawo jest „nade wszystko świętościa”" (etwas Heiliges Überhaupt), albowiem nie każde prawo i nie od razu posiada nie tylko legitymację obowiązywalności, lecz także znamiona etyczne. Źródłem formalizmu uprawnień i obowiązków prawnych jest różny stopień rozwoju pojęcia wolności, której „obiektywnym” istnieniem (Dasein) jest właśnie prawo. Wolność zatem - a nie przymus - jest w ogóle podstawa, z której prawo wyrasta. Koncepcja Hegla, co zresztą wykazuje Siemek, różni się diametralnie od koncepcji pozytywistycznych, w tym zwłaszcza od nakazowej teorii prawa. I nie chodzi tu wyłącznie o poziom legitymizacji. W porównaniu z bardziej formalnym, tj. abstrakcyjnym i dlatego też bardziej ograniczonym prawem takie prawo, które odpowiada wyżej rozwiniętemu duchowi społecznemu, będzie zarówno konkretniejsze, jak i bogatsze i „prawdziwie powszechne"; wszelako, każdemu stopniowi rozwoju idei wolności odpowiada właściwe dlań prawo. Jeśli tylko ludzkość dojrzeje do idei wolności obejmującej ludzkość właśnie - nie zaś tylko poszczególne indywidua, grupy, narody i georegiony - możliwe będzie „prawo ducha światowego" (das Recht des Weltgeistes), powiada Hegel w paragrafach 29-30 Filozofii prawa. Z nich też inspirację czerpie Siemek.

\section{Prymat prawa etycanego nad abstrakcyjnym}

Z uwagą odnotować należy postulat etycznego rozwoju prawa abstrakcyjnego, sformułowany przez Siemka w reakcji na pozytywistyczne (w szerszym od metodologicznego znaczeniu tego terminu) ograniczenia obejmujące pojęcie prawa również pod koniec XX w., zwłaszcza w kontekście spuścizny po autorytarnym ustroju, z którą polski system prawny uporał się dość prędko. Pytanie, czy osiagnął on przynajmniej podstawowe jakości etyczne i nie ustaje w osiaganiu kolejnych, pozostaje póki co bez odpowiedzi, ponieważ pobieżna choćby odpowiedź na nie wymagałaby zdefiniowania kryteriów etyczności, a dalej - zastosowania ich do kluczowych 
aspektów prawa i praktyk prawnych. Jest to zadanie złożone, wymagajace dalszych badań; dlatego poprzestaniemy tutaj na omówieniu różnicy między prawem „niższym” i „wyższym” oraz wstępnym zdefiniowaniu kilku kryteriów pozwalajaccych zidentyfikować tę różnicę.

Ponad abstrakcyjne prawo w ogólności, abstrakcyjne zaś „prawo jednostek jako prywatnych osób” niepowiązanych ze sobą żadnymi relacjami zapośredniczajacymi w szczególności, przedkłada więc Siemek „wyższe prawo etycznej, bo interpersonalno-publicznej wspólnoty, wyznaczającej właściwą przestrzeń ludzkiej wolności i racjonalności w strukturze nowoczesnego uspołecznienia przez indywidualizację. Ta właśnie strategia - powiada - z powodzeniem jest urzeczywistniana w całej filozofii społecznej Hegla"14 i będzie ona kontynuowana również przez Siemka.

Kluczowy element tej strategii dotyczy, rzecz jasna, społecznie zapośredniczonej legitymizacji prawa. To ona nadaje etyczny ciężar aktowi prawotwórczemu, tj. nomothesis, którego źródłem nie będzie już legislacyjna samowola, lecz „wola wspólna”. Ten nowy, etyczno-nomotetyczny akt opiera się na takich regułach i procedurach, które wyrastaja z interpersonalności uznania i wzajemności umowy. „Umowa - jak podkreśla Hegel - zakłada jako przesłankę, by ci, którzy umowę zawieraja, uznawali się wzajemnie jako osoby"15. Do umowy przynależy nie tylko kognitywne w swej istocie uznanie, ale także normatywne w swej istocie zobowiązanie wzajemne - jest tu wszak mowa o „odnoszeniu się woli do woli” jako relacji zapośredniczającej. Weźmy własność, która mamy „już nie tylko za pośrednictwem jakiejśs rzeczy i mojej podmiotowej woli, lecz również za pośrednictwem woli innej osoby i tym samym woli wspólnej"16. Wobec tego do pojęcia prawa (tutaj - własności) przynależy to, że „każdy z woli własnej i z woli tego drugiego przestaje być właścicielem, pozostaje nim i staje się nim”"17.

${ }^{14}$ M. J. Siemek, Filozofia spetnionej nowoczesności, dz. cyt., s. 41.

is Georg W. F. Hegel, Zasady filozofii prawa, § 71, przeł. A. Landman, BKF, PWN, Warszawa 1969.

${ }^{16}$ Tamże, $\$ 185$.

"Tamże, § 74; por. E. Nowak, Autonomia jako zasada etyczności. Kant, Fichte, Hegel, Wydawnictwo UWr, Wrocław 2002, s. 317 i n. 


\section{B2| Ewa lowak |}

Uniwersalnie nośny dla prawa stosunek „woli do woli” jest stosunkiem interpersonalnym, którego wyczerpujacą konstrukcję, również w kontekście historycznej dialektyki wzajemnego uznania, znajdujemy w pracach Siemka i komentarzach do nich ${ }^{18}$. Dlatego nie będziemy go tutaj szczegółowo analizować; dość powiedzieć, że przepracowany przez Hegla między okresem jenajskim i berlińskim, powraca on w Filozofii prawa bynajmniej nie jako prosta relacja afirmatywna między indywiduami, lecz jako wiążąca i zuniwersalizowana wymienność zobowiązań umownych, „zapośredniczajaca” i legitymizujacca wyrażoną w normie prawnej dyrektywę zachowania ludzkiego, które w przytłaczajaccej większości jest zachowaniem $w$ stosunku do innej osoby, jej integralności psychofizycznej, jej uprawnień, jej własności (również intelektualnej) itd. Zapośredniczenie to zachowuje nadzwyczajną wagę zarówno w obu kluczowych momentach, tj. powstawania prawa i jego stosowania, czyli orzecznictwa jako „systemu zinstytucjonalizowanych procedur, poczynając od procedury sądowego przewodu" ${ }^{2}$.

Siła tego społecznie afirmującego i zarazem zobowiązującego - a więc nakładającego określone wymogi na legislaturę i sądownictwo zapośredniczenia - wyraża się najwłaściwiej w taki oto sposób: nakaz prawny staje się jednocześnie wiqżacy etycznie (sittlich), czyli z formalnego przechodzi w substancjalny wtedy i tylko wtedy, gdy daje się sprowadzić do imperatywu sformułowanego przez Hegla w § 36 Zasad filozofii prawa:

Nakazem prawa jest przeto - bądź osobą i respektuj innych jako osoby.

Starannie różnicując „dwa pojęcia prawa” ${ }^{20}$ i wydobywając z pierwszego z nich typową dla niego formalno-abstrakcyjną nakazowość, z drugiego zaś - zobowiązanie etyczne zapośredniczone w zasadzie wzajemnego uznania, ugruntowuje więc Siemek etyczny prymat prawa, które zawdzięcza swoją moc obowiązywania

\footnotetext{
18 Zob. tamże.

19 M. J. Siemek, Filozofia spetnionej nowoczesności, dz. cyt., s. 93.

${ }^{20}$ M. J. Siemek, Hegel i filozofia, dz. cyt., s. 89 i n.
} 
1. „nowoczesnej zasadzie uspołecznienia pośredniego jako uspołecznienia poprzez ujednostkowienie, zróżnicowanie i dystans" 21 ,

2. zasadzie wzajemnego uznania ujednostkowionych podmiotów.

Tym samym proponujemy, by ten etycznie i niejako substancjalnie umocowany - bo wyraźnie już nie tylko pozytywny i nie tylko abstrakcyjnie-formalny, wywodzący się z zewnętrznego autorytetu - „nakaz prawa” uznać za formułę prawa etycznego wedle Hegla i Siemka.

Fundamentalne dla etycznie wysyconego pojęcia prawa byłoby to, że otwiera się ono nie tylko na inkluzję potrzeb społecznych, generujących treść norm prawnych, ale i na dyskursywną legitymizację obowiązywania na poziomie komunikacji i argumentacji. Zdaniem Siemka, tego rodzaju inkluzywność jest bowiem w Filozofii prawa „wszechobecna”, i pomimo kontrastujących z nią fragmentów świadczących o przywiąaniu Hegla do silnego państwa, idzie tu przecież o prawo jednostek uspołecznionych na sposób „ekonomiczno-mieszczański”, a zarazem „cywilno-obywatelski”22. Nowym i nośnym elementem pojęcia prawa wedle formuły Hegla i Siemka jest bowiem „moment wzajemnego uznania”, za sprawą którego nowoczesny „system prawny nieodwracalnie już eliminuje pierwotna - przednowoczesna - walkę o uznanie i taki stosunek jak panowanie i niewola"'. Aby eliminacja taka rzeczywiście miała miejsce, prawo powinno z niej wyrastać i mieć w niej swoją podstawę. Wszak twórcy etycznego prawa sami urzeczywistniaja etyczność i tworzą społeczność wolną od relacji dominacji i podległości. Jeśli zaś prawo dopiero deklaruje lub nakazuje obywatelom porzucenie tej relacji, to znaczy, że przynajmniej pewna część - na tyle znacząca, że stała się adresatem prawa - nie urzeczywistnia tego warunku etyczności, który polega na eliminacji stosunku panowania i niewoli. Społeczeństwo nie jest wolne, dopóki choć jeden z jego członków pozostaje niewolny.

Siłą rzeczy, substancjalne kryterium zapośredniczenia i eliminacji stosunku panowania i niewoli nie mogło być spełnione s. 68 .

"M. J. Siemek, Filozofia spetnionej nowoczesności-Hegel, dz. cyt.,

n Tamże, s. 70 . 


\section{B4 | Ewa llowak |}

w prawie mitycznego władcy Teb i nie jest spełnione przez żadne prawo, które czerpie legitymację obowiązywania z pozytywnego aktu legislacyjnego, zorganizowanego przymusu lub samej skuteczności nakazu kierowanego przez organy władzy do pod-władnych. Ta ostatnia, radykalnie asymetryczna relacja sama zresztą zakłada i wzmacnia prymat prawa, któremu do etyczności daleko, a które - zależnie od stadium etycznego rozwoju obywateli - zachowuje legitymację oparta na przymusie, albowiem - jak powiada Fichte, najwyraźniej z myślą o przednowoczesnym społeczeństwie - prawo musi dać się wymusić, nawet gdyby ani jeden człowiek nie przejawiał dobrej woli. Jeśli jednak przymus prawny ma służyć dominacji i kontroli jednych nad drugimi, tj. uzyskiwaniu zachowań pożądanych zamiast zachowań społecznie pożądanych z uwagi na osobowe traktowanie wzajemne, dopóty system prawny utrwala i legitymizuje przednowoczesną asymetrię dominacji i podległości, jako system sam w sobie nieetyczny, czyli ograniczony do prawa pozytywnego. System taki podpada pod kategorię jeszcze „niższego prawa” aniżeli prawo abstrakcyjne, posiadające - jak to już pokazano wyżej - pewne formalne znamiona etyczne. Dla odmiany, „nieusuwalnie prawna istota etyczności wypływa... ostatecznie stąd, że stuszne prawo, das Recht, samo w sobie jest już z góry ,etyczne"' 23 i jako takie przeważa wewnętrznym autorytetem etycznym nad każdym innym prawem, które swój autorytet zawdzięcza jakimkolwiek innym kryteriom.

Przypuszczalnie, nowoczesne systemy prawne w rozumieniu Siemka spełniają szereg kryteriów etycznych, zachowując przy tym niezbywalne znamiona formalno-abstrakcyjne. Powstaje jednak pytanie, czy ich kondycja etyczna może ulec radykalnej i substancjalnej poprawie, jeśli systemy prawne podlegaja powolnej ewolucji. Zdaniem Siemka, obok opisanych wyżej, do kluczowych kryteriów etycznego prawa należą pojęcia osoby i podmiotowości, wolności i autonomii występujące w prawie, a także kryterium samowiedzy, wszak „właściwym podmiotem tego prawa jest wolna i samowiedna osobowość człowieka"24. Nade wszystko jednak,

\footnotetext{
B Tamże, s. 50.

24 Tamże, s. 50.
} 
podmiot jako taki jest osoba. W osobowości zawarte jest to, że ja jako ten oto [podmiot] całkowicie ze wszystkich stron... określony i skończony, jestem jednak bezwzględnie czystym odnoszeniem się do siebie samego i w ten sposób uświadamiam sobie siebie w skończoności jako to, co nieskończone, ogólne i wolne ${ }^{25}$.

Również Kantowska zasada „społeczeństwa obywatelskiego rządzącego się prawem", gdzie wszystkie jednostki dokonują samoograniczenia własnej, zewnętrznej wolności „pojęciem możliwej wolności innych”, aby - jak podkreśla Siemek - „zrealizować ludzką etyczność”26, może być przydatne w ocenie etycznej kondycji prawa. Rozstrzygajacy w tej materii byłby sondaż społeczny, zawierający pytanie w rodzaju „czy jesteś gotów ograniczyć własną swobodę w zakresie..., aby twoi współobywatele mogli korzystać z tej samej swobody na równi z toba - i czy zasada taka zasługuje na właczenie do konstytucji”.

Częstotliwość występowania pojęć takich jak osobowość, autonomia, wolności osobiste itd. nadaje wprawdzie etyczna jakość prawu na poziomie językowym, lecz od interpretacji tych pojęć - i zwłaszcza od reguł interpretacyjnych zapewniających jednolitą interpretację na poziomie orzecznictwa zależeć będzie to, w jaki sposób prawo traktuje człowieka, kierując do niego określone dyrektywy dotyczące zachowania. Intuicyjnie wydaje się, że pojęcia takie jak osoba, podmiot, indywiduum, autonomia itd. oscylują bliżej żywego człowieka, dając wyraz jego godności, kruchości, afektywności, a zarazem przydając prawu humanistycznego patosu. Na pewno jednak wymowa tych terminów zależy od interpretacji i kontekstu użycia. Dla porównania dwie zupełnie odmienne w tonie wypowiedzi o prawie autorstwa Carla Schmitta i G. W. F. Hegla, w których przewijają się te same lub podobnie abstrakcyjne - kategorie:

Istnieje autonomia w prawie, ale jej nośnikiem jest wyłącznie państwo jako jedyny podmiot „etosu w prawie" (Ethos im Recht)... Autonomia w prawie oznacza co innego aniżeli autonomia w etyce, gdzie indywiduum

ن G. W. F. Hegel, Zasady filozofii prawa, dz. cyt., § 35.

${ }^{2}$ M. J. Siemek, Wolność, rozum, intersubiektywność, dz. cyt., s. 119 . 


\section{B6 | Ewa llowak |}

traktowane jest jako posiadacz autonomii (Inhaber der Autonomie)... W państwie żadne indywiduum nie posiada autonomii... Konkretne indywiduum z krwi i kości... jest całkowicie przypadkowa jednostka (Einheit), zbitka atomów, której postać, indywidualność i wyjątkowość odpowiadaja postaci, indywidualności i wyjątkowości kurzu i pyłu, którego słup unosi się w powietrzu wraz z podmuchem wiatru... Pytanie, jak pomóc temu empirycznemu indywiduum, nie jest już pytaniem filozofii prawa... Wszystko, co może uczynić filozofia prawa, to wskazywać, jak bardzo pozbawiona sensu jest władza bez prawa i jak pozbawione sensu jest indywiduum wydane takiej władzy ${ }^{27}$.

Schmitt rozważa tu status indywiduum w obliczu przednowoczesnego, silnego, autorytarnego prawa i państwa, dając nam poczucie jego znikomości. Hegel zaś - zupełnie inaczej interpretujac te same pojęcia - redefiniuje status indywiduum na 100 lat przez Schmittem w duchu emancypacji człowieka wobec prawa oraz emancypacji prawa wobec władzy politycznej. Jednakże losy obu tych indywiduów pozostają wydatnie zależne od instytucji państwa, definiowanego przez obu myślicieli w sposób skrajnie odmienny:

Jeśli w despotycznych państwach... jednostce nie przysługiwała żadna wewnętrzność i nie miała ona w sobie żadnych uprawnień, to w świecie nowoczesnym jednostka chce być szanowana z racji swej strony wewnętrznej. Połączenie obowiązku z prawem ma tę podwójną stronę, że to, czego państwo wymaga jako jej obowiązek, jest także bezpośrednio jej prawem, gdyż państwo nie jest niczym innym jak organizacją pojęcia wolności. Określenia indywidualnej woli zostały przez państwo doprowadzone do obiektywnego istnienia i dopiero dzięki państwu osiagaja one swoja prawdę i swoje urzeczywistnienie. Wyłącznym warunkiem osiagnięcia celu szczegółowego i dobrobytu jest państwo ${ }^{28}$.

Jednym z elementarnych kryteriów pozwalających ocenić etyczność prawa powinna być także jego komunikatywność, skoro źródłem legitymizacji i beneficjentem etycznego prawa ma być świadoma, „samowiedna osobowość” każdego

1 Carl Schmitt, Der Wert des Staates und die Bedeutung des Einzelnen, Verlag J. C. B. Mohr (Paul Siebeck), Tübingen 1914, s. 102.

18 G. W. F. Hegel, Zasady filozofii prawa, dz. cyt., § 261, Uwagi. 
obywatela, niekoniecznie członka prawniczej elity. Dalsze kryteria powinny umożliwiać oszacowanie, na ile sformułowania norm i przepisów prawnych zapośredniczone są w umowach i zobowiązaniach wzajemnych, omówionych wcześniej jako jedno z kryteriów substancjalnie etycznych. Odniesień takich powinno być stosunkowo wiele, skoro

tym, co rzeczywiście rządzi i włada w całej dziedzinie prawa abstrakcyjnego, sa komunikacyjne stosunki wzajemności. [Zwłaszcza] jego główne kategorie - tak „własność” jak i „umowa” - mają u swych podstaw całościowy system ekwiwalentnej wymiany wzajemnego uznania, w której wszyscy uczestnicy nawzajem siebie respektuja jako wolne i równe osoby oraz odpowiednio do tego się traktuja ${ }^{29}$.

Siemek od początku podkreślał, że wzrost etycznej jakości prawa nie oznacza redukcji - zwłaszcza radykalnej redukcji znamion abstrakcyjnych. Te ostatnie, choć zapewne usuwalne, nie stoją na przeszkodzie rozwojowi etycznemu. Sposób odczytywania prawa już w warstwie jego zapisu wydatnie zależy od poziomu wiedzy, a także samowiedzy prawnej. Prawo może ukazywać oblicze ,janusowe”, tzn. zarówno abstrakcyjne jak i etyczne, i nie ma w tym nic niestosownego. Jednak niemożność dostrzeżenia znamion bądź jakości etycznych w natłoku znamion abstrakcyjnych świadczy wymownie o tym, że ustawodawca uprzywilejowuje znamiona abstrakcyjne, zaniedbuje zaś - etyczne, przez co prawo przestaje być postrzegane przez człowieka jako istnienie i gwarancja jego wolności, a staje się źródłem ślepego i niezrozumiałego przymusu.

$\mathrm{w}$ istocie przecież jest to wciąż jedno i to samo pojęcie prawa, które jest tu rozważane z dwóch różnych stron i odpowiednio do tego jawi się jako „słabe” albo „mocne”... Widać to całkiem wyraźnie nawet już na obszarze prawa abstrakcyjnego, które w rzeczywistości jest znacznie bardziej konkretne, niż sugeruje jego nazwa ${ }^{30}$.

Skoro rozpoznanie etyczności prawa zależy od przyjętej optyki i metodologii badawczej, nie da się wykluczyć, że niektóre oceny mogą być nieadekwatne, jeśli np. kryteria

${ }^{19}$ M. J. Siemek, Filozofia spetnionej nowoczesności-Hegel, dz. cyt., s. 51 .

30 Tamże, s. 50. 


\section{B38 | Ewa llowak |}

stosowane są wybiórczo, a treść poszczególnych norm lub aktów prawnych rozważana w oderwaniu od innych (zwanych niekiedy kompetencyjnymi). Badacz etycznej jakości prawa, podobnie jak każdy obywatel, powinien mieć jednak dostęp do dokumentacji procedur zastosowanych w jego tworzeniu oraz interpretacji. W takim przypadku badaniem powinny być objęte instytucje odpowiedzialne za te czynności, stosowne protokoły, reguły interpretacyjne itp. W zupełnie wstępnych badaniach z pomocą przyjść moga proste kryteria, pozwalające np. określić,

czy człowiek podlegajacy normom bierze udział w ich tworzeniu, czy nie. Innymi słowy, czy zobowiązanie skutkuje z jego wola, bez jego woli, czy ewentualnie wbrew jego woli. Taką różnicę określa się zwyczajowo jako przeciwieństwo między autonomią i heteronomia, teoria prawa kieruje się nim zasadniczo w sferze prawa państwowego. Tutaj zaś występuje ona jako różnica między demokracją i autokracja, albo między republiką i monarchią ${ }^{31}$.

\section{4. „Wyisse" prawo jako etyanoosis samoistna}

"Tragedia w łonie etyczności” zrodziła wiele wyzwań pod adresem klasycznej filozofii prawa. Pierwsze z nich narzuca sam dualizm prawa i moralności, przybierajacy mniej lub bardziej dolegliwe społecznie formy w zależności od tego, czy zadowolimy się prawem rozumianym $\mathrm{w}$

ograniczonym i znacznie węższym zakresie ważności, mianowicie jako samo tylko prawo abstrakcyjne... jako podrzędny, bo tylko formalny i zewnętrzny przedsionek do „wyższych” dziedzin moralności, a zwłaszcza etyczności. W tym ostatnim znaczeniu można zasadnie mówić o „słabszym” albo „gorszym” czy też „niższym” pojęciu prawa ${ }^{32}$,

również w świetle wypreparowanej z kontekstu uzasadnienia i eksponowanej przez tzw. ekskluzywny pozytywizm nakazowości i przymusowości; czy też takim prawem się nie zadowolimy i - jako użytkownicy krytycznej władzy sądzenia - dążyć będziemy do nadania prawu postaci etycznie

"Hans Kelsen, Reine Rechtslehre, hg. v. M. Jestaedt, Mohr Siebeck, Tübingen 2008, s. 117-118.

$3 l$ M. J. Siemek, Hegel i filozofia, dz. cyt., s. 90. 
dojrzałej, bezustannie domagając się i doszukując poza jego „formalno-proceduralną organizacją" tego, co Siemek nazywa „inaczej ukształtowaną normatywnościa, w której przednowoczesny etos... zostaje wyparty i zastapiony przez zasadę uniwersalnego zapośredniczenia, właściwą już oswobodzonej... indywidualności człowieka nowoczesnego". Wówczas dopiero okazać się może, że owo prawo „nie tylko jest czymś możliwym i rzeczywistym, lecz także może zostać prawomocnie i prawowicie ugruntowan[e] jako etycznie samowystarczaln $[\mathrm{e}]{ }^{\prime 33}$.

Dopiero w ten sposób skorygowana normatywność prawa znajdzie legitymizację w „zasadzie samoistnej, w sobie nieskończonej osobowości jednostki" ${ }^{34}$ i będzie można upatrywać w niej ,istnienie samowiednej wolności”35, a nawet dopowiada Siemek - „,samą istotę i kwintesencję ,duchowej’, tj. ludzko-społecznej rozumności jako takiej" ${ }^{36}$. Owa samowiedna rozumność dostrzeże również prawidłowości rysujące się w jej własnej pracy, po heglowsku zwanej „praca pojęcia”. Pierwsza z nich będzie taka, że w społeczeństwie obywatelskim prawem staje się to, co już wewnętrznie dla niego prawne $(R e c h t)^{37}$, o czym była już mowa przy okazji substancjalnego znamienia etycznego prawa. Druga byłaby taka, że tylko etyczne prawo mieć może wyłącznie takie społeczeństwo, które aktywnie wytwarza i podtrzymuje mechanizmy oraz instytucje pozwalajace dyskursywnie odsłaniać i uniwersalizować owe treści „wewnętrznie prawne”, czyli posiada niwelujaca abstrakcyjne znamiona prawa albo wysycająca je etycznie

strukturę intersubiektywnej normatywności, która swe roszczenia do ważności powszechnej może legitymizować - i dopiero dzięki temu przeforsować wyłącznie za pośrednictwem świadomości i woli wszystkich jednostek. Filozoficzna teoria nowoczesności... opiera się na tym właśnie założeniu i odkryciu ${ }^{38}$.

${ }^{3}$ M. J. Siemek, Filozofia spetnionej nowoczesności, dz. cyt., s. 74 .

${ }^{34}$ G. W. F. Hegel, Zasady filozofii prawa, dz. cyt., s. 88.

35 Tamże, s. 52.

${ }^{36}$ M. J. Siemek, Hegel i filozofia, dz. cyt., s. 89.

37 Por. G. W. F. Hegel, Zasady filozofii prawa, dz. cyt., § 217.

${ }^{38}$ M. J. Siemek, Filozofia spetnionej nowoczesności, dz. cyt., s. 74. 
Inna prawidłowość, natury epistemicznej, polegałaby na tym, że samowiedza społeczna pozwala jednostkom dostrzec zależność między żywionymi przez nie ideałami (z porządku aksjologicznego) a rzeczywistymi prawami (z porządku normatywnego). Ideały i prawa, podobnie jak argumentacje normatywne, sa bowiem bytami o genezie społecznej. Świadomość ta może umacniać obywateli w dążeniu do etycznego prawa, a zwłaszcza w dążeniu do „prawowitego i prawomocnego", jak pisze Siemek, ugruntowania wspólnych norm, składających się na wspólne prawo. Ideały i prawa są wprawdzie różne w swej modalności, ale uspołeczniona świadomość potrafi je porównać i uchwycić „ich wzajemna relację" ${ }^{39}$, poddając osądowi rozbieżność między nimi. Daje tu o sobie znać Kantowska władza sądzenia jako „władza rozumienia" wzajemnej relacji pomiędzy prawem postulowanym przez moralna autonomię i prawem, jakie istnieje i jakiego „fenomenalną faktyczność” rozpoznaje i porządkuje intelekt. Dlatego Siemek określił władzę sądzenia jako „Rozum sam - jeden i jedyny, gdyż myślący najgłębszą podstawę jedności swego jedynego świata" ${ }^{40}$. Aby ten śmiały ,skok' z królestwa filozofii Kanta do królestwa filozofii Hegla nieco zamortyzować, wykorzystał on dodatkowo pojęcie rozumu J. G. Fichtego, wyłożone w Eigene Meditationen über die Elementarphilosophie w znaczeniu, które doskonale przystaje do podmiotu zdolnego rozpoznać i ocenić, w jakiej mierze społeczna normatywność realizuje „własny” ideał:

dążność władzy sądzenia zmierza... ku temu, że chce ona porządkować niezależnie od tego, co dane... ale również może ona dążyć do tego, by prawo (Gesetz) mieć w sobie samej; i to byłaby kantowska refleksyjna władza sądzenia, heautonomia ${ }^{41}$.

${ }^{39}$ M. J. Siemek, Idea transcendentalizmu u Fichtego i Kanta, Państwowe Wydawnictwo Naukowe, Warszawa 1977, s. 49.

40 Tamże, s. 153.

41 Johann G. Fichte, Eigene Meditationen über Elementarphilosophie, GA II, 3, s. 240-241. Do interpretacji takiej uprawnia sposób odczytania przez Siemka „praktycznej” filozofii Kanta w duchu fichteańskim. Podkreśla on bowiem, że „problematyka ,rozumu praktycznego' i w ogóle fichteańskiej myśli etycznej... jest zarazem myślą społeczno-polityczna”, M. J. Siemek, Idea transcendentalizmu..., dz. cyt., s. 185; prymat myśli społeczno-politycznej rozciaga Siemek również na Heglowską filozofię prawa i - co istotne - także na moralność jako pierwotny li tylko 


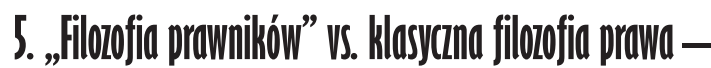 Hans Kelsen i Marek J. Siemek}

Dlaczego dążenie do etycznego bądź „słusznego prawa”42 miałoby się powieść w stuleciu, które należało do najbardziej spójnej i konsekwentnej, naukowo bowiem wyłożonej, Czystej teorii prawa Hansa Kelsena i szerokiego nurtu komentatorów, naśladowców, ale i krytyków, skoro ta pragnęła puścić w niepamięć dorobek klasycznej filozofii prawa z jej ociężałymi i mętnymi kategoriami, z „ideologią legitymizacji” na czele, którą należy bezwzględnie unicestwić zczególnie w kontekście państwa? ${ }^{43}$

Czysta teoria prawa jest teoria prawa pozytywnego. Prawa pozytywnego po prostu, a nie jakiegoś określonego porządku prawnego... Jeżeli określa się ona jako czysta teoria prawa, to dlatego, że ma się ona odnosić poznawczo tylko do prawa, i z punktu widzenia takiego właśnie poznania wyłączyć z prawa wszystko, co nie należy do niego w ścisłym sensie. To znaczy - pragnie ona uwolnić teorię prawa od wszystkich obcych jej elementów. Jest to jej podstawowa zasada metodologiczna. Wydaje się to oczywistością. Wgląd w tradycyjną teorię prawa, taka, jaka rozwijała się w XIX i XX wieku, pokazuje wyraźnie, jak bardzo oddaliła się ona od wymogu czystości ${ }^{44}$.

Zarysowując tutaj etyczne imperium prawa według projektu Marka J. Siemka, korzystaliśmy z klasycznych teorii i kategorii, tradycyjnych pojęć i narracji, ignorując wymóg czystości i apel o wykreślenie ze współczesnego słownika

żywioł rodziny. „Już na pierwszy rzut oka widać, że zarówno rodzina, jak i państwo w ostatniej części Filozofii prawa nie stanowią żadnej alternatywy dla społeczeństwa obywatelskiego, lecz są najwyraźniej jego rodziną i jego państwem. Obojga, rodziny i państwa, nie należy więc uważać ani za wymagające troskliwej ochrony residua, ani za jakieś dopiero świadomie projektowane bastiony obronne ,prawdziwej etyczności', których sens i zadania polegałyby na tym, by wspólnotowy etos ,ogólności' ocalić przed wszechobecną inwazją tych w nieskończoność potęgujących się egoizmów, jakie stanowią wszak samą istotę obywatelsko-społecznej ,szczegółowości. Wręcz przeciwnie...”, M. J. Siemek, Filozofia spetnionej nowoczesności - Hegel, dz. cyt., s. 75-76.

${ }^{4 l}$ M. J. Siemek, Hegel i filozofia, dz. cyt., s. 89 i n.

${ }^{43}$ H. Kelsen, Reine Rechtslehre 1934, Studienausgabe der 1. Auflage 1934, Mohr Siebeck, Tübingen 2008, s. 137, przekł. własny.

${ }^{44}$ H. Kelsen, Reine Rechtslehre, dz. cyt., s. 1. 
prawniczego „bliżej nieokreślonych, wieloznacznych słów”, takich jak sprawiedliwość, legitymizacja, wartość, wola prawodawcza, dobro powszechne, a nawet trybunał konstytucyjny, co postulował Kelsen w 1929 r. jako sędzia i radca konstytucyjny przy kanclerzu Austrii, Karlu Rennerze. Zgodnie z art. 1 Konstytucji Austrii autorstwa Kelsena, źródłem prawa pozostaje lud ${ }^{45}$ - co brzmi skądinąd jak jedno ze znamion etycznego prawa. Tymczasem na kartach rozprawy Wer soll der Hüter der Verfassung sein (1931) Kelsen uznał „całkowitą wolę ludu” za „demokratyczną fikcję”. Przywołujac postać Kelsena w kontekście rekonstrukcji pojęcia etycznego prawa według Hegla i Siemka, pragnę jedynie wskazać, że ten pierwszy - jako zawodowy jurysta w roli filozofa prawa, i ten drugi - jako zawodowy filozof w analogicznej roli, uosabiają dwa radykalnie kontrastujące ze sobą podejścia badawcze do prawa, od zakresu tego pojęcia poczynając. Krytyka pod adresem bardzo waskiej metodologii badań nad prawem usunęła w cień radykalny pozytywizm, który w swoim czasie dał wyraz zniecierpliwieniu świata prawniczego wobec zaniedbania „wymogu czystości”.

Dziś, gdy minęło stulecie Kelsena, musimy mieć świadomość, że klasyczna filozofia prawa przywróciła poczucie słusznego i etycznego prawa po erze ślepego posłuchu wobec nakazowości prawa. Zauważmy, że Marek J. Siemek, będac klasycznym filozofem prawa, ani razu nie legitymizuje zasady nakazowości bądź przymusu jako podstawy uzyskiwania powinnych zachowań ludzkich, która sformułował Kelsen i która można określić jako tezę o separacji przymusu wobec wolności. Nie przystaje ona bowiem do tradycji, w świetle której prawo definiowane jest jako „istnienie wolności”. Jak podkreśla Siemek w swoich pracach poświęconych J. G. Fichtemu, właśnie u tego myśliciela istota filozofii prawa „streszcza się w pytaniu o to, jak przekształcić żywiołowa wzajemność przymusów w racjonalny przymus wzajemności (...) Prawo, Recht, z istoty swej bierze pod uwagę tylko ,miłość własną jednostek, tj. ich egoistyczny interes" ${ }^{46}$. Fichte bowiem przyjmował na sposób

${ }^{45}$ Hans Kelsen, Wesen und Entwicklung der Staatsgerichtsbarkeit, VVdsTRL 5, 1929, s. 29-30.

${ }^{46}$ M. J. Siemek, Hegel i filozofia, dz. cyt., s. 196. 
pozytywistyczny, że „przedmiotem wspólnej woli jest $w z a$ jemne bezpieczeństwo... każdy podporządkowuje cel wspólny swojemu celowi prywatnemu (na to też obliczona jest zasada przymusu, Zwangsgesetz)... Prawo musi dać się wymusić nawet, gdyby dobrej woli nie miał ani jeden człowiek" ${ }^{47}$.

Z legitymizacji nowoczesnego porządku prawnego, a nawet już z deliberacji nad nia, Siemek świadomie wykluczył przymus - nie dlatego, iżby prawo miało być zupełnie pozbawione sankcji przymusu. Po prostu w paradygmacie deliberującej wspólnoty rozumnych prawodawców przymus i siła nie stanowią już argumentów na poziomie stosowności, zwłaszcza w kontekście etyczności prawa. Śladem Kanta i Habermasa, Siemek przenosi punkt ciężkości z argumentu siły na siłę argumentu, z władzy - na moc rozumu, z politycznej auctoritas - na wewnętrzny autorytet prawa. Staje się dzięki temu krytykiem pozytywizmu w godnym i wielkim stylu, znanym nam ze Sporu fakultetów, gdzie sam Immanuel Kant nie szczędzi złośliwej krytyki ani jurystom, ani władzom wydziedziczajacym obywateli z ich prawa do formowania woli prawotwórczej, z dążności do etycznego prawa, a nawet z użycia własnego, rozumnego osądu. Zatem to raczej Siemkowi aniżeli Kelsenowi należy się prawo głosu w kwestii tego, jak powinna wyglądać filozofia prawa XXI wieku.

Jurysta teoretyk jako autorytet $\mathrm{w}$ dziedzinie tekstu... poszukuje prawa zabezpieczającego „moje i twoje” nie $\mathrm{w}$ swym rozumie, lecz w kodeksie, otwarcie poddanym i usankcjonowanym przez najwyższe władze. Nie należy od niego oczekiwać dowodów prawdy i praworządności tych praw, podobnie jak i obrony przed wysuwanymi przeciwko nim zarzutami rozumu. Albowiem tylko rozporządzenia sprawiają że coś jest prawem, zaś pytanie, czy same rozporządzenia zgadzają się z prawem musi zostać przez prawnika odrzucone jako niedorzeczne. Byłoby absurdalne uchylać się od posłuszeństwa pewnej zewnętrznej i najwyższej woli z powodu, że jakoby nie zgadza się ona z rozumem. Bo prestiż rządu polega właśnie na tym, że pozostawia on swym poddanym wolność

${ }^{41}$ J. G. Fichte, Grundlage des Naturrecht, GA I/3, s. 432-433, w przekładzie M. J. Siemka, w: M. J. Siemek, Hegel i filozofia, dz. cyt., s. 162. 
wydawania sądów o prawie i bezprawiu nie zgodnie z ich własnym pojęciem, lecz z zarządzeniami władzy ustawodawczej ${ }^{48}$.

Powyższe odnosi się nie tylko do stanowienia i nowelizacji prawa z uwagi na jego walor etyczny, którego nie należy mylić z „czyjąkolwiek i jakkolwiek rozumianą moralnościa”, jak podkreśla Siemek. Chodzi bowiem o rozumność artykulacji, wnioskowań, uzasadnień i rozstrzygnięć także na poziomie wykładni prawna - albowiem najwięcej nadziei na tę rozumność pokłada Kant w „osobie sędziego, ... realnego komentatora praw" ${ }^{49}$. Poprzez swoją radykalną tezę o społecznej w gruncie rzeczy separacji prawa (nie zaś tylko separacji wobec ideologii, polityki i moralności) pozytywizm prawniczy utwierdził w nas przekonanie o specyfice, hermetyczności i niedostępności „rozumności prawniczej” oraz „sztucznego rozumu i osądu prawnego" dla profanów. Tymczasem w ostatnim czasie to sami profesjonaliści podkreślają doniosłość klasycznego ujęcia rozumności i władzy sądzenia, wywodzącego się z tradycji kantowsko-heglowskiej i aktualizowanego w filozofii prawa Siemka. Na zmiany te zwraca uwagę Tomasz Pietrzykowski, i to by znaczyło, że filozofia i prawo dojrzały do tego, by dostrzegać wspólny, społeczny interes i współdziałać na rzecz jego realizacji w coraz bardziej etycznym prawie:

niezależnie od tego, na ile sztuczna jest rozumność samej treści norm wyznaczających wzorce powinnego zachowania się w danych sytuacjach, nie musi to przekładać się na jakąkolwiek sztuczność procesów opartych na nich rozumowań, zmierzajacych do wyprowadza z nich konkretnych rozstrzygnięć. Poddanie decyzji podejmowanych w poszczególnych wypadkach ogólnym regułom nie jest bynajmniej cechą charakteryzująca jedynie rozumowania prawnicze. Ma miejsce również $\mathrm{w}$ innych dziedzinach rozumowania praktycznego - od moralności..., medycyny, inżynierii, po pieczenie chleba. Teza o istnieniu artificial reason nie implikuje zatem bynajmniej tezy o istnieniu artificial reasoning prawników ${ }^{50}$.

${ }^{48}$ I. Kant, Spór fakultetów, przeł. M. Żelazny, Toruń 2003, rozdział B, Specyfika fakultetu prawnego, s. 63-64.

49 Tamże, s. 64.

so Tomasz Pietrzykowski, Intuicja prawnicza, DIFIN, Warszawa 2012, s. 203-204. 